\title{
DERIVATIVES AS RISK MANAGEMENT TOOL IN SHARIA'H
}

\author{
Malieka Farah Deeba Malik \\ Head of Department Law \\ Bahria University, Department of Law, Islamabad \\ hodlaw.buic@bahria.edu.pk
}

\author{
Adil Sharif \\ Director General Law, \\ Private Power Infrastructure Board, Ministry of Energy, Government of Pakistan \\ adil.sharif@ppib.gov.pk
}

\begin{abstract}
This paper identifies the various risks in sukuk structures, sharia'h permissible risk hedging techniques and certain regulatory, legal and infrastructural challenges which this novel product is facing in the modern global financial system. The analysis demonstrates that though sukuk is a viable device for asset-monetization, its complex structure necessitates the development of innovative sharia'h permissible risk management tools which can be formulated within the sharia'h framework of Al-Khiyar. Since the sukuk originated from emerging markets which are mostly characterized with secrecy and institutional imbalances, these circumstances create great hardships for the bankers and regulators to observe the progress of the corporate being financed. In this research it is argued that this situation strongly demands greater transparency and disclosure in sukuk structures coupled with profound regulatory, legal and institutional reformation in emerging markets. The research finally argues that sustainable market for the sukuk is doomed with uncertainties, unless the innovative process for sharia'h compatible risk hedging techniques continues and aforesaid reformations are initiated.
\end{abstract}

Keywords: Sharia, Sukok, Risk, Islamic, Finance, Management.

\section{INTRODUCTION}

In Islamic finance industry sukuk has emerged as a cutting-edge phenomenon, paving the way for multi-billion asset monetization (Hussain, Shahmoradi, \& Turk, 2015). The greatest potential of the novel product lies in its capability of transforming an asset's future cash flows into present cash flows (Adam \& Thomas 2004). Since the structure of sukuk is woven around the concept of conventional securitization, there are various risks underlying the same (Hidayah, Lowe, \& De Loo, 2021). These risks, despite similarity of the sukuk structure with that of securitization, are unique because of different contours of Islamic financial contracts (IFCs) underlying the structure. Given the different nature of risks underlying sukuk, the risk management strategy will undoubtedly be different from that of conventional one (Nasir \& Farooq, 2017). This is because of the fact that mostly conventional risk management tools are structured around interest or over speculation which do not hold any place in Islamic finance. On the other hand, the present day scenario of the Islamic finance is that there is dearth of risk management tools, the absence of which poses great challenge as to sukuk like products' viability in longer run in highly competitive modern global financial system (GFS). This situation makes a stronger case for research in this field. The main focus in this paper is not on the theoretical aspects of risk management tools. This work rather is an attempt to apply risk management techniques to real transactions. The analysis will be focused just on those tools which have been endorsed by the majority of scholars. The main argument in this paper is that sukuk structures despite gaining robust response in global financial markets are prone to various risks and lack adequate transparency and favorable accounting, legal and regulatory infrastructure. This situation mandates for development of Sharia'h compliant risk hedging tools coupled with profound reforms at institutional and regulatory level in the emerging markets, the origin of sukuk (Alswaidan, Daynes, \& Pasgas, 2016).

In this paper an analysis has been made regarding various risks, the techniques for hedging those risks and disclosure and transparency (D\&T) issues in sukuk structures. We have to be selective 
in our approach therefore the most important risks will be discussed. The first part of the paper provides for basic conceptual framework of Islamic finance on the basis of which sukuk structure has been evolved. The second part deals generally with the nature and outline of legal and financial structures of sukuk. Thereafter, the third part explores different risk scenarios and their implications on further developing a thriving sukuk market. In the fourth part an effort has been made to evolve a risk management strategy in sukuk structures which in the first place is sharia'h compliant and secondly meets the practical needs of Islamic finance industry. The last part concludes the discussion.

\section{Conceptual Framework of Islamic Financial System}

The paradigm of Islamic financial system (IFS) is comprised of rules and laws, collectively called as sharia'h which governs socio-political cultural and economic aspects of Islamic societies. Sharia'h rules have been developed out of the principles as enunciated in Quran, practices done and explanations given (commonly known as Sunnah) by the Holy Prophet Mohammad (peace be upon him) and further elaborated by scholars (jurists) in the light of Quran and Sunnah. Although an attempt to write a brief introduction of the basic concepts of the IFS in itself is beset with difficulties yet the approach herein will be to lay down the basic outline which is comprehendible for a person who is unfamiliar with tenets of the IFS. The outline of basic paradigm is summarized as under.

\section{Prohibition of Riba (Usury or Interest)}

Prohibition of Riba, a term implying an increase, is central tenet of Islamic financial system. Riba is any return/reward or compensation which is charged on a debt or loan advanced or on its rescheduling. In other words, it is any positive fixed, predetermined rate tied to the maturity and the amount of principle (Abdou, 2015). The rationale behind the prohibition is that "in the Islamic scheme of finance and business, money on its own may not generate profits" (Nagaoka, 2012, pp. 114-136). Equity demands that lenders and borrowers should share rewards as well losses in equitable fashion and real productivity should be exhibited underlying the all financial transactions (Askari, Iqbal, \& Krichene, 2012).

\section{Prohibition of Gharar (Excessive Uncertainty)}

Excessive uncertainty or gharar is the second exception to the general rule of trade by mutual consent. The IFC discourages the transactions which are based on excessive risks, extreme uncertainties and gambling which brought about enmity and disputes amongst the contracting parties. El Gammal defines gharar as "trading of risk" (El-Gamal, 2000) whose extreme form is gambling and a zero-sum game wherein one party loses and the other wins. Prohibition of gharar is often to justify prohibition of such conventional financial practices as speculation, short selling and derivatives (Hassan, Aliyu, \& Brodmann, 2017). Gharar in terms of contract includes two sales in one, down payment (Urboon) sale, the "pebble", "touch" and "toss" sales, suspended (mu'allaq) and future (mudhaf) sales. Gharar in the object implies ignorance as to genus, species, attributes, quantity, specific identity, time of payment in deferred sales, inability to deliver and contracting on nonexistent object (Witbrodt, \& Shapiee, 2014). Given that risk is the essence of business activity it does not mean that risks in all of their manifestations are prohibited. Rather excessive risks in transactions are prohibited.

"Sharia'h prohibition of gharar may be thought of as one way that Islam manages risk" (Taman, 2011) by keeping the unbridled speculation under guard. On the other hand, risk being the formative element of business activity is the basis for innovation. Conventional finance is now "well poised" to include the highly speculative products as risk management tools.

\section{Prohibition on Unethical Investments and Services}

Investments dealing with alcohol gambling, drugs or anything else that the sharia'h considers unlawful are deemed undesirable and prohibited. This is IFS's ethical aspect which though limitizes the array of assets available yet it imparts on the Muslims to invest in products and assets which bring about real development in society. In present day financial system "market discipline has transformed these ethical issues into stock screening methods" (Tariq, 2004).

\section{Contract as the Essence of business activity}

At the very foundation of the IFS lies the fundamental concept of sanctity of contract wherein all parties are under sharia' $h$ obligation to disclose material information regarding the subject of contract. This feature is intended to reduce the risk of asymmetric information and moral hazard and maintains that Muslims transact by means of a specific well-defined contract (Alam, Gupta, \& Shanmugam, 2017). Basically, the IFCs can be broadly divided into two parts: debt-based contracts 


\section{Derivatives As Risk Management Tool in Sharia'h}

and equity based contracts. These contracts serve as the basic building blocks of more complex financial instruments like sukuk (Kok, 2014).

\section{Debt Based Contracts}

There are four different types of debt based contracts.

\section{Murabaha (Price Deferred Sale)}

This is a cost-plus financing sale contract whereby the seller purchased the goods desired by the buyer and sells them at an agreed marked-up price, the payment being settled within an agreed time frame, either in installments or in lump sum (Chapra, 2007). "Murabaha is only valid where the exact cost of a commodity can be ascertained" (Usmani, 1998 at 103). The seller bears the risk of the goods until they are delivered to the buyer. Murabaha is one of widely used instrument for short-term financing. "Islamic banks use the concept of Murabaha sale to satisfy the requirements of various types of financing, such as the financing of raw materials, machinery, equipment and consumer durables as well as short-term trade finance" (Ausaf, 1993).

\section{Ijarah (Lease)}

An ijarah contract is like a conventional lease agreement whereby the usufruct of subject matter, capable of generating cash flows over time, of the contract like airplane, cars or ships etc. are sold to the lessee at a predetermined price (Elasrag, 2011). The lessor retains the ownership with all its enabling rights. However, it differs from conventional lease in the sense that the duty to maintain the asset is generally of the lessor unless the defect or loss to the asset was done by lessee out of negligence or misuse. However, one distinguishes feature is that in ijarah contract a stipulation binding the other party to sell or purchase the lease asset at the end of lease period is prohibited on basis of the principle of Sharia' $h$ which mandates that "one transaction cannot be tied up with another transaction so as to make the former a pre-condition for the other" (Kamali, 2007).

\section{Salam (Object Deferred sale) and Istisna' (Object and Price Deferred Sale)}

For the purpose of validity of a sale contract it is pertinent principle of Islamic sharia'h that the commodity must be in existence and in physical or constructive possession of the seller. There are two exceptions to the general rule. One is salam and the other is Istisna' (Muhammad, \& Chong, 2007).

"A salam is a sale whereby the seller undertakes to supply some specific goods to the buyer at a future date in exchange of an advanced price fully paid at spot" (Dchieche, \& Aboulaich, 2016). For the purpose of valid salam contract it is necessary that buyer pays the price in full at time of affecting of sale. Commodities must be specified in quality and quantity with the time and place of delivery. An inherent risk in this arrangement is that a bank providing salam facility may not be able to sell the commodity should the other party opt to backtrack the promise.

"Istisna' or commissioned manufacturing is a contract wherein one party buys goods and the other party undertakes to manufacture according to specifications given in the contract."(Ahmad, \& Hassan, 2006). As against the salam in istisna' the price may also be deferred either in installments or parties may agree for one installment at up front and balance at later stage. In practice Islamic banks employ back-to-back istisna' to finance manufacturing and construction whereby 'in the first istisna' the bank acts as a seller accepting a long -term schedule of payments from its customer, while in the second istisna' the bank acts as a buyer, paying the manufacturer over shorter period with progress payments" (Berschadsky, 2000). In istisna' contract time of delivery is not fixed. However, the flexibility in the structure is that "the price of istisna' may be tied up with the time of delivery" (Lahsasna, Hassan, \& Ahmad, 2018). One prominent risk feature of istisna' contract is that a customer may opt to back-track the contract before manufacturer has started work on the product.

\section{Equity based contracts}

There are various equity based financial contracts, however, only those contracts will be discussed which are also building block for the most of the issuance of sukuk.

\section{Modarabah}

A contract between two parties, capital owner(s) or financier(s) and investment manager wherein profit is distributed between the two parties in accordance with the ratio upon which they agree at the time of the contract (Dusuki, 2009). In modarabah contract financial loss is only borne by the financier(s) (Iqbal, \& Llewellyn, 2002). The entrepreneur bears the loss in terms that he does not have any reward of his services. A modarabah can be created in the two-tier form when after having the deposit from the investor the bank which works as modarib in turn invest these funds with entrepreneurs whereby financial institution become capital investor (Siddiqui, 1998). 


\section{Musharaka}

A musharaka contract is a similar kind of modarabah contract with the difference that in former both partners participate in the management and the provision of liquid capital. Profits are distributed between partners in accordance with the ratios initially set, whereas loss is distributed in accordance with the proportion of share in capital. There are two kinds of musharaka: one permanent musharaka wherein the IFI participates in equity of a company and is entitled for annual pro rata profits and second diminishing musharaka wherein the equity is redeemed by the partner which eventually matures in the ownership of the asset or project.

\section{Tradability of Islamic Financial Assets}

From the supra financial contracts, musharaka, modarabah and ijarah certificates are tradable in secondary markets because of the fact that these certificates exhibit ownership of the underlying assets with the certificate holder (Moghul, \& Safar-Aly, 2014). On the other hand certificate issued on the basis of istisna', murabaha and salam creates a debt obligation therefore they cannot be traded but "at discount or par value" (Tariq, \& Dar, 2007). Further if the instruments represent multiple assets for example ijarah, istisna' and salam then for the purpose of tradability the dominant share must be of the instrument which represents the ownership of equity, or underlying assets (Radzi, \& Muhamed, 2019). Similarly, principle and return on any financial instruments based on musharaka or modarabah cannot be guaranteed by the issuer (Dusuki, 2010).

\section{Contours of Sukuk structures}

The term sukuk denotes a claim akin to note or certificate implying a right of ownership of the underlying asset as against mere financial claim. The singular of the sukuk is sukk which represents either a proportional or an undivided interest or title in an asset or class of assets. Sukuk according to definition given in The Accounting and Auditing Organization for Islamic Financial Institution (AAOIFI) Sharia'h Standards No. 17 are certificates of equal value representing, after closing subscription, receipt of the value of the certificates and putting it use as planned, common title to shares and rights in tangible assets, usufructs, and services, or equity of given project or equity of a special investment activity (Alamad, 2017). It implies an undivided beneficial ownership of an underlying asset wherein the risk and return associated with cash flows generated by a particular asset is rested on investor. "Whether or not the ownership interest drives to tangential ownership rights, it is those rights that carry with them the right to appropriate share of cash flow or other benefits and risks of ownership." (Dewi, 2012). One of the condition precedents of issuance of sukuk is the existence of sharia'h compliant assets on the balance sheet of government, monetary authority, company, the banking and financial institutions. Unlike conventional asset backed securitization structure it is necessary that asset pool must not predominantly comprise of debts receivable. It does not entail a debt liability for the issuer but the sukuk holder under the issuance of the certificate shares the return as the stipulations set in the offering document. On the building block of Islamic financial contracts AAOIFI defines fourteen kinds of sukuk certificates ${ }^{1}$. The detail of the certificates is given in the Appendix.

The most of the permissible sukuk are admissible for trade in secondary market as per sharia'h requirements except salam, istisna, murabaha and some forms of muzara'ah and musaqah when holder of sukuk does not own land. ${ }^{2}$ Sukuk can be further classified with regard to the suitability of the issuer. For example pure Ijarah sukuk, based on stand-alone assets, hybrid/pooled sukuk, comprising of istisna', murabaha and ijarah assets but with ijarah with dominant share, viable rate redeemable sukuk, zero-coupon non-tradable sukuk, primarily based on istisna and murabaha assets and embedded sukuk with put and call options ${ }^{3}$.

\footnotetext{
${ }^{1}$ For detail list of permissible sukuk see AAOIFI Standard 17. The summery is given in Appendix . Even list given in the Standard is not exhaustive as many different other forms of sukuk can also be issued generating regular future flow of cash. For example a copyright owner may issue sukuk on the basis of his copyright to mobilize his funds.

${ }^{2}$ See paragraphs 5/2/14 to 5/2/18 AAOIFI Sharia'h Standard 17.

${ }^{3}$ For the detail see Latif, A.M. \& Dr. Hassan,A. "Issuance of Sukuk landmark towards Islamic Capital Market in Brunei” Borneo Bulletin Nov. 2005 available at http://www.micg.net/art10.htm
} 
The Sukuk issuance can be based on either existing or specific assets which may be generated in future. For the practical purposes the negotiability of the sukuk is linked with the ownership transfer of the asset when the same has been "issued after receipt of the value of the sukuk, the closing of the subscription and employment of the funds mobilized for the purpose for which the sukuk were issued" (Adam, \& Thomas, 2004).

\section{Legal and Financial Structure of Sukuk}

The legal structure and format of sukuk being quite similar to the US Trust Certificates allows it to be listed and traded. For the practical purposes almost all form of implementation can be employed for offering of sukuk except the structures which are repugnant to Sharia'h principles. Analogous to conventional securitization the use of Special Purpose Vehicle (SPV) as a bankruptcy remote entity is very common in which case either beneficial or full ownership of underlying assets, capable of being "estimated with reasonable degree of accuracy", (Kothari, 2006). are transferred to SPV through a pass-through mechanism. However, alternatively various forms of trust vehicles can also be employed which hold the title of assets on behalf of the investors. Mostly the SPV is incorporated abroad keeping in view the availability of bankruptcy-remote legal forms of business organizations on the line of Anglo-Saxon trusts, favorable tax treatment and low incorporation and administrative costs.

The SPV acquires underlying assets through true sale transaction and on the basis of such acquisition issues sukuk to the investors. It is essential that nature of pool of assets must carry similar risk weight. However, "if income assets of various risks level are pooled together in separate groups, instruments of as many classes can be engineered to suit the preference of different investors" (Jobst, 2007). Through the SPV, the proceeds of the sukuk issue are transferred to the originator. Unlike conventional securitization mere assignment of the cash flows are not permitted rather a sukuk securitization structure "will require a higher connectivity to the underlying asset and operating business" (Thomas, Cox, \& Kraty, 2005). For the purpose of good rating and subsequent marketability of the product the credit and liquidity enhancement facilities can also be availed which must be permissible under sharia'h provided "the underlying assets are not recharacterized" (Thomas et al., 2005). For that matter third party guarantees, retaining reserve funds from the cash flows of the underlying assets and/or additional assets pledging (over collateralization) to hold the underlying assets are sharia' $h$ permissible modes of credit and liquidity enhancement. Further, legal issues which are important to be considered before the structuring of the sukuk transactions include: structure and domicile of the SPV, tax issues, implications for regulatory regimes where securities are to be listed, respective contracts, the role of parties, nature of classes of shares and different level of investors. A typical sukuk structure is given below

Exhibit. 1 A typical sukuk structure

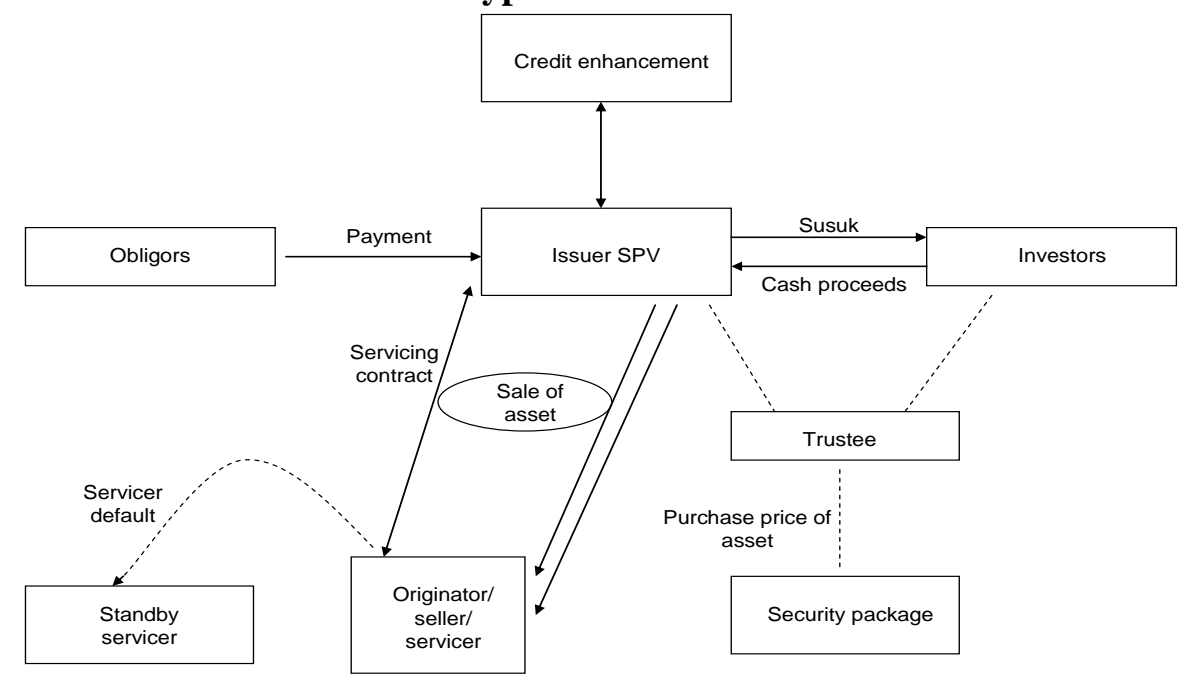

\section{Ijarah sukuk}

The most commonly used form of sukuk is sukuk al ijarah (lease by back). The seller, a government or corporation, as the originator transfers the certain asset such as lands, building or machinery to SPV for a fixed price on the basis of undertaking by SPV to lease the same back to originator. The 
SPV then, on the basis of acquisition of assets for the purpose of raising finance, issues sukuk certificate to investors (the sukuk holders) at par value in an amount equal to purchase price by transferring the beneficial interest in the assets to the sukuk holders. The SPV being trustee on the basis of trust declaration holds the assets on the trust for the investors. Thereafter the assets are leased back to the corporate or government or its any other affiliated entity. The SPV then collects the periodic rentals from the same. The stream of rentals is benchmarked to London Inter Bank Offering Rate (LIBOR). The transaction duration depends upon the term of lease which may be short, medium long as per the terms of contract. Then on the event of maturity of transaction or early dissolution the SPV sells the assts back to originator at a predetermined price. As ijarah sukuk are typically issued for period of at least five years it is usual for the investors to receive direct guarantee from the originator for the SPV obligations (Wilson, 2008). These kinds of guarantees also bring about the good rating of the deal. A similar kind of structure was used in recent sovereign issues by the State of Saxony-Anhalt (Germany), Government of Pakistan and Kingdom of Bahrain. All the issues were oversubscribed.

Exhibit. 2

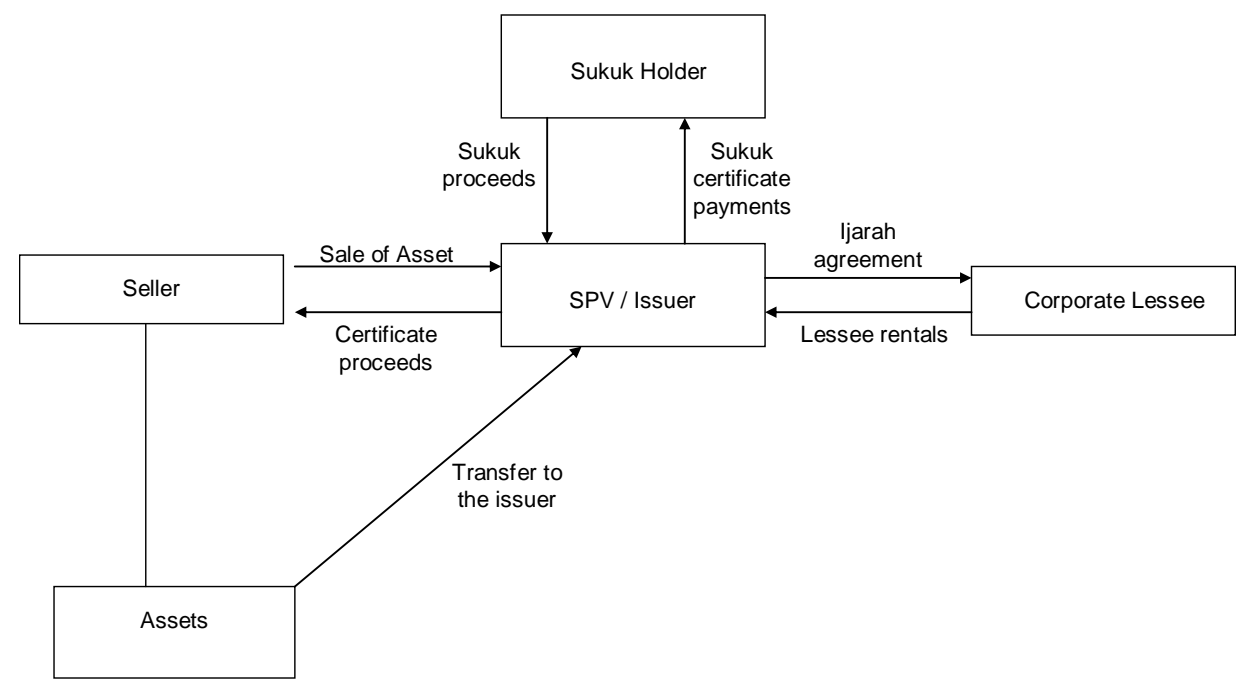

\section{Case Study _ Qatar Global Sukuk ${ }^{4}$}

In October 2003 Government of Qatar in order to monetize the asset of Hamad Medical City located in Doha, Qatar established a joint venture SPV along with Qatar International Islamic Bank and HSBC. Under the structure the SPV purchased a parcel of land from the government of Qatar and resold the same to the investors on the basis of trust certificates (sukuk) worth US\$700 million on the declaration of trust. The SPV on behalf of sukuk holders leased back the parcel to the government under a Master Ijarah Agreement. As per the terms of the contract the rentals were to be paid on semiannually basis which was benchmarked to LIBOR plus the margin. The returns on the sukuk were guaranteed by the Government of Qatar. The sukuk were listed on Luxemburg Stock Exchange. The deal was rated by Standard \& Poor's as A+. In the transaction each sukuk holder has an undivided beneficiary right to the land parcel till the maturity of the transaction in 2010. The delayed payment of rental issue was resolved with the stipulation in the contract that Government of Qatar would donate late payment amount to the charity of issuer's choice. It is worth mentioning here that Qatar Global sukuk was first listed sovereign sukuk structure in civil law jurisdiction. As the Qatari law does not recognize trust law therefore trust relationship between sukuk holders and the issuer was established under English Law trust instrument whereby an agent SPV was established in Qatar acting on behalf of an onshore SPV, the trustee. The structure is illustrated in Exhibit 3.

\section{Istisna sukuk}

Istisna sukuk is generally used for the project finance. Under sukuk al istisna' structure the bank contracts with a purchaser through an SPV to deliver the contracted assets on a future date assuming

\footnotetext{
${ }^{4}$ The information has been gathered from various sources including Offering document of Qatar Global Sukuk, Nathif \& Thomas, Ali Arsalan Tariq, . and Islamic Capital markets products as cited in the bibliography
} 
the responsibility for the completion of the project and then through contractual arrangement appoints subcontractor to complete the project under its supervision by entering into another parallel istisna' contract. When the project gets completed the project assets are transferred to the SPV which is responsible for the payment of pre-determined purchase price. In this transaction the financing comprised a profit margin included in the purchase price and is usually benchmarked to LIBOR. On the basis of expected stream of payments sukuk are issued.

\section{Exhibit. 3. Source Lovells}

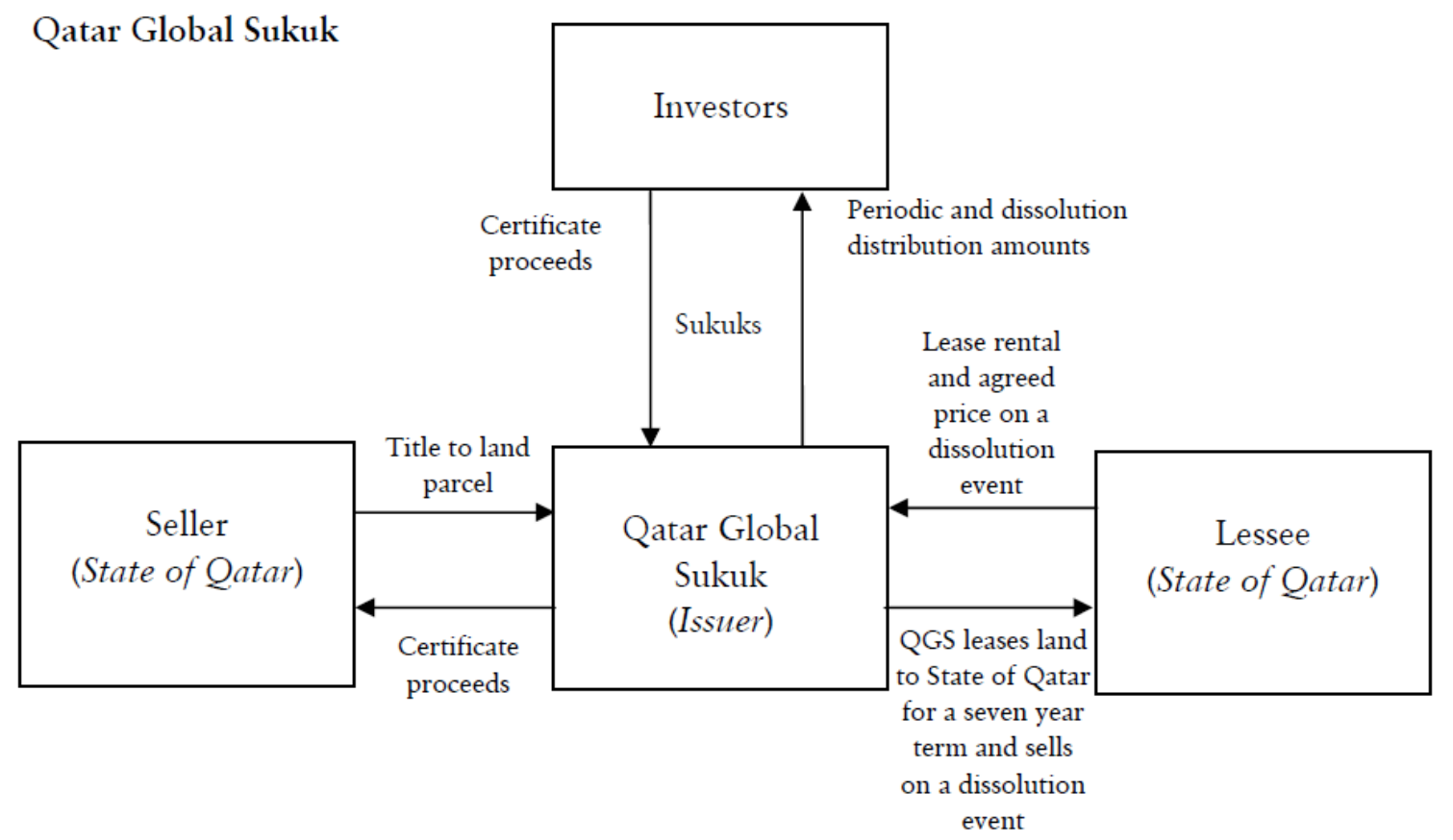

In a hybrid istisna'/ijarah sukuk the SPV enters into a contract for work with the contractor or the seller for the project and a forward lease with the seller. On the basis of the same, the SPV issues sukuk to raise the finances for the project to be constructed under the istisna' contract. The sukuk proceeds received by the SPV are then utilized in construction of the project and the contractor after build-transfer arrangement transfers the project to the SPV which further leases the same to corporate. The corporate pays the advance rent until the project is under construction and then, after completion and transfer of project under lease contract, it pays rents as lessee. These rents serve as the return on sukuk certificates.

\section{Diminishing Musharaka sukuk}

Musharaka sukuk though appeared recently in the sukuk market yet it is gaining popularity in Malaysia and Gulf (Wilson, 2008). The most popular structure until today is based on the concept of diminishing musharaka. The model is based on the concept of partnership between a government (or corporate) and the private parties with the provisions that the government (or the corporate) ultimately becomes the sole owner of the project (Linder, 1999). In this structure an Islamic bank or company provides an up-front investment funding to the originator with both parties forming an SPV to administer the sukuk. The financial structure is quite similar to ijarah sukuk except the difference that the payment flow is disparate. The originator transfers the assets to the SPV while entering into a partnership contact. The Islamic investors similarly purchase sukuk but representing the partnership in the venture. As per the legal structure both issuer and the sukuk holders are partners in the SPV but share of the investors in the SPV diminishes over a period of time with the payment of installments by the issuer for the repurchase of the asset. For the investors the aforesaid installments and rental payment for the use of assets until the event of maturity of the transaction form the stream of income. The difference between ijarah, istisna', salam and musharaka sukuk is that in the former the investors receive their capital in the end of the transaction whereas in later they receive payments in installments, and the final installment terminating the partnership (Ahmad, \& Shabbir, 2006).

\section{Sukuk Market}


Before the emergence of the sukuk in global market Islamic financial institution in order to manage liquidity were narrowly focused in continuous murabaha transactions (Rethel, 2011). There was dearth of parallel and back-to-back quality transactions for the management of balance sheet. The global competitiveness where conventional debt based finance is dominant would not let the nascent industry to survive which was primarily linked to transactions limited to certain sharia'h compliant commodities. Given the size of total assets of Islamic Finance Institutions (IFIs) worldwide estimating to exceed US $\$ 250$ billion and growing at an estimated $15 \%$ a year Islamic financial industry desperately requires financial engineering to meet the competitors in the global markets (Baruya, 2017). Thus illiquid assets on the balance sheets of the IFIs and were asking for liquidity tools but unfortunately there was no product which might meet the need of capital market. Thanks to the sukuk structures which allows the IFIs to tap the global markets by transferring the pool of illiquid assets through Islamic securitization without much headaches. "The instrument has confirmed its viability as an alternative mean to mobilize long-term savings and investment to huge investor base that is happy to invest in formats compliant with the sharia' $h$ "(Adam \& Thomas 2004).

Despite the global viability of the sukuk product in term of low cost of capital efficiency and regulatory advantages the market so far is concentrated mainly in two biggest Islamic capital hubs, Malaysia and Middle East "with former accounting for the overwhelming number of issues although the amounts are significant in Gulf where average size of each issue tends to be larger" (Wilson, 2008). The capital market has also witnessed non Islamic issuers which include World Bank, Asian Development Bank, Nestle and Government of Saxony-Anhalt in Germany (Hussey, \& Ong, 2005).

The empirical evidence clearly establishes that sukuk market "within short span of less than five years have reached an impressive size of US\$ 30 billion" (Hussain, Shahmoradi, \& Turk, 2016). With the Muslim population comprising 1.5 billion on global, worth US\$3.1 trillion Islamic funds with per annum growth of $12 \%$ to $15 \%$ and over 250 IFIs operating in about 75 countries worldwide, the sukuk market has great prospects to grow further ${ }^{5}$

\section{Identification and classification of Risks surrounding sukuk structures}

In perspective of conventional finance, risk is the "volatility of unexpected outcomes usually the value of assets or liabilities of interest" (Alessandri, \& Drehmann, 2010). Since sukuk structures transform different set of assets into securities, the risk transformation quality underlying each sukuk is also different "depending on:

a) Fixed or flexible return structure in the contract between issuer and investor;

b) Nature of fixed or flexible rat contract between issuer and originator;

c) Time to maturity

d) The composition and nature of the underlying asset;

e) Put or call options given to the originator or the investor;

f) Payment capacity of the originator or its guarantor;

g) Tradability and liquidity of the sukuk"( Ali, 2005).

Risk may be classified in different ways. One broad classification of the risks may be made in terms of business and financial risks. Business risks are associated with the financial institution's operations which are mainly brought about by the product market variables. On the other hand, financial risk arises due to volatilities in financial market variables. In sukuk structures, some risks are endogenous depending on management of overall structure while others are exogenous. The former includes credit risk, liquidity risk, operational risk whereas later comprises of market risk, legal risk and sharia' $h$ compliance risk.

\section{Credit and counter party Risk}

Credit risk refers to the inability or failure of counter party in meeting "its obligation timely and fully in accordance with agreed terms" (Ahmed, 2005). Usually this problem may be the outcome of the asymmetric information regarding the actual profit of the firm. Credit risks are unique and higher in sukuk structure owing to the specific nature of financial contracts underlying the same particularly in the absence of any mechanism of rescheduling of debt or higher mark-up in case of default. Thus counter party will be more inclined to default on its obligations. For example, in salam sukuk, default may occur in the failure of delivery of commodity in time or agreed quality. In ijarah there may be

\footnotetext{
${ }^{5}$ The data has been collected form "Islamic Capital Markets" available at http://www.klse.com.my/website/bm/products_and_services/islamic_capital_market.html
} 
default on the part of lessee to pay rentals in time. However, in floating rate ijarah risk level is lesser serious. Similarly, in istisna' contract, contractor may decline to provide service as per agreed terms which might give the buyer a right to cancel the contract.

\section{Liquidity risk}

Liquidity risk can be defined as "the risk of loss arising from a lack of cash or equivalents or, more specifically, the risk of loss arising from an inability to obtain funding at economically reasonable levels or sell or pledge an asset at carrying prices in order to cover an expected or unexpected obligation" (Banks, 2005). This is essentially a loss suffered by an investor in an attempt to transform the asset in cash that is very vital for the continuing business operations. As some of sukuk structures are built on the debt-based instruments for example murabaha, salam and istisna', they cannot be traded in the secondary markets because of prohibition of sale of debt. Malaysian sukuk market is an exception in the sense that in Malaysia sale of debt has been held permissible on par value. However, this position is not acceptable in most of Middle East region.

The duration of transaction is very crucial for liquidity risk management purposes. The longer is the duration of sukuk the higher is the risk of liquidity. Secondly liquidity risk prevailed even in sukuk which were inherently tradable in the secondary market although they were listed on stock exchanges. The main reason behind this seems to be that "market was starved for so long of high quality sovereign paper that investors have, thus far, been purchasing to hold" (Thomas et al, 2005). The establishment of Liquidity Management Centre in Bahrain is step in right direction. Yet there is a lot to be done in this regard.

\section{Market Risk}

"It is the risk of an unexpected loss to the bank's income due to unexpected changes in market prices" (Thomas et al, 2005). Market risk is outcome of the macro and micro variables. Volatilities in prices in various markets generate different set of risks. Broad classification of market risks is mainly comprised of interest rate risk, foreign exchange risk, equity price risk and commodity price risk (Thomas et al, 2005). These risks are exogenous in nature depending on government's economic and political policy shifts therefore as such there is no hard and fast mechanism to judge and anticipate such risks well before their occurrence.

Interest Rate or Rate of Return Risk

"Interest rate risk is the exposure of a bank's financial condition to movements in interest rates" (Thomas et al, 2005). Although sukuk structures does not entail charging or paying of interest yet they are exposed to interest rate risk because of stream of the cash flows being benchmarked to LIBOR, and a fluctuation in same can affect overall yield curve on the sukuk. Particularly, fixed-income sukuk like ijarah, salam, istisna' etc. are much prone to rate of return risk similar to fix-rate conventional bonds (Alzahrani \& Megginson, 2017). Although Islamic finance experts in the backdrop of sharia'h objection as to LIBOR are proposing that instead of LIBOR the rate of return should be benchmarked against GDP growth rate in case of sovereign sukuk and share prices index in case of corporate sukuk yet these benchmarks are also volatile; the issuer as well as investors will be exposed to the rate of return risk.

\section{Foreign Exchange Risk}

It goes without saying that currency risk has direct impact on the proceeds of sukuk depending upon the currency of denomination of issue. The risk is much aggravated if the denomination of currency of underlying assets is different from that of the currency of sukuk proceeds. Most of the sovereign sukuk till to-date has been issued in US Dollar whereas the proceeds of assets are in local currencies given the fact that most of the projects are located in local markets. Thus in the event of currency mismatch or rise in value of Dollar the issuers are prone to the exchange risk inherent in the wake of a volatile currency markets. If the sukuk is denominated in local currency, then foreign investors will face the same risk. This mismatch was manifested in IDB sukuk wherein IDB unit account Islamic Dinar was depreciated and as a consequence IDB incurred profit. However, any appreciation in Dollar would expose IDB to currency loss. If all other conditions are similar currency risk will be the same for all cases of sukuk. On the other hand, the sukuk which are liquid or which bear relatively short term will be less exposed to currency risk.

\section{Operational Risk}

Operational risks are the outcome of human and technical errors or accidents which bring about direct or indirect loss resulting from frail and inadequate internal process, technology failures, less trained 
professionals in the organization or any exterior event having direct bearing on the sukuk structure. Generally, these risks are not because of special nature of transaction based on sharia'h but inherent in this kind of structures similar to risks in conventional bonds. However, risk quantification methodology is different from conventional finance transaction. Since sukuk implies complex structures involving various players like originator, SPV, guarantors, credit enhancement agency, trustee, investors etc. Therefore, there may be numerous operational risks at each contractual level amongst the parties to the deal. For example, if the cash flows from the underlying assets are commingled with the other funds of the originator acting as servicer, there may be a risk that the coupon payment is delayed in adjustment of account. Similarly, if cash flows are to be transferred to an offshore escrow account, then delay may cause foreign exchange risk exposure because of the sudden rise or fall in the currency. Thus all such risks either related to infrastructure, technology, system failures or regulatory compliance raise a strong probability of affecting the advantages of the transaction.

\section{Legal Risk}

Given the different paradigm of Islamic financial contracts, sukuk structures are exposed to certain legal risks for example enforcement of contracts, bankruptcy remoteness issues, choice of law and forum etc. Since most of sukuk transactions originated from emerging markets, the legal and institutional framework of those jurisdictions is prime factor in assessment of legal risk underlying the structure. As a matter of fact except Malaysia and Bahrain no other Islamic country on the globe has financial and legal structure wherein Islamic securitization structure may squarely fit (Alswaidan, 2017). The major concern in this regard are title risk, consolidation risk and claw back. For example, in Qatar Global Sukuk the absence of binding precedents on bankruptcy remoteness issues by courts and clarity as to how the Qatari Courts would deal with this issue pose substantial risks for the whole transaction. In case of Hanco Sukuk, the first of its kind which has been structured on movable assets, vehicle fleet, and two-tier SPV framework, one in Saudi Arabia and the other in Jersey, the proceeds of the sukuk are collected by local SPV and transmitted to an offshore account thus creating risk as if the transaction is loan ${ }^{6}$.

\section{Agency or Moral Hazard risk}

Emerging from various contractual relationships among the various parties and stemming out of asymmetric information in sukuk, agency risk is very vital. Since as per the requirement, the SPV has to depend upon various parties without being able to monitor their actions directly that allows the agents to have cirtain degree of latitude for discretion. They can pursue their own private ends to the detriment of the SPV as well as sukuk holders. Agency risk becomes worst in the cases where the agent withholds the crucial information thus damaging the transparency of the structure. Example of such risks may include but not limited to:

- withholding of credit default information by the servicer

- failure of servicer in appropriate and in time reporting of loss

- insufficient and inadequate monitoring of the transaction by the trustee

- attempts on the part of originator to influence the rating process

\section{Sharia'h Compliance Risk}

Sharia'h compliance risk is unique in sukuk structures. There may be different instances when Sharia'h compliance issues can seriously undermine value of the sukuk assets. Although rating agencies do not take into account the factor of Sharia' $h$ compliance however deeper analysis reveals that there are certain instances which tend to impair the integrity of sukuk structure. For example sharia'h impermissibility of derivatives to hedge risks in sukuk would be a concern for the rating agency to grant particular rating (McMillen, 2006).

Secondly most of Islamic contracts become binding after one party to the contract have performed certain acts in furtherance of obligations. Before the issuance of sukuk such contract cannot be enforced in certain jurisdictions giving rise to potential risk. Similarly, in sale contracts Sharia'h provides the buyer an option of inspection and he can reject deal on the basis of the same. This risk though can be easily managed but in rating perspective it can have deep impact (Colon, 2010).

\footnotetext{
${ }^{6}$ Lovells's guide for clients available at http://www.yasaar.org/pubs/20177\%20Islamic\%20finance\%20client\%20note1.pdf
} 
Another prominent example of sharia'h risk is regarding governing law of the contract. Usually, the contracts provide that the governing law will be subject to Sharia'h principles which create legal uncertainty as to choice of law issues.

Role of Sharia'h boards at institutional level is very complex with reference to sukuk structure. In perspective of Islamic investors in sukuk transaction sharia' $h$ compliance will depend on the reputation and integrity of the sharia' $h$ scholars involved. However, in the absence of uniform appointment mechanism, qualification of Sharia'h scholars, dearth of sound practices as to decision making process and ambiguity as to status of decision, sukuk structures are exposed to greater degree of risk.

\section{Legal Framework in Risk management}

The stunning complexities of international and domestic markets of finance have brought deeper concern for realization of risk management crucial role in finance of modern day (Crotty, 2009). Response of Conventional markets of finance to challenge development of swaps, credit derivatives, options, futures, and forwards (Huault, \& Rainelli-Le, 2009).

Since Islamic finance's basic building blocks are prohibition of gharar, risk sharing, and riba, risk management conventional tools on touch stone of these principles unanimously declared prohibited (Obaidullah, 2008). Conventional tools tend to separate risk from real activities as Islamic form of risk management entails embodiment of risk in services and goods (Frame, 2002). Conventional derivatives shift risks to those willing to bear them as "Islamic instruments likely to shift risks to persons willing and able to bear them""?

In the perspective of Islamic Finance "higher risk often attributes to lack of risk management tools and absence of infrastructure and institutional arrangement" (Al Swailem, 2006, P.139). Process of financial engineering entails complex instruments development utilizing basic building blocks or repackaging and unbundling different components of existing financial instruments (Li, 2003). However, in Islamic finance, process development product, besides riba and principles of gharar, has to qualify certain requirements. Al Swailem (2006) narrows down principles of development product as following:

- Principle of balance_ between self and other interests, between for- non-profit and profit activities and between cooperative relations and competitive relations.

- Interdependence_ relationship between independent persons utilizing benefits of cooperation to achieve result.

- Acceptability_ economic dealings generally acceptable unless stated by Sharia'h otherwise.

- Consistency_ form of product should serve means and substance conform to ends.

On touch stone of above principles conventional derivatives in forms of forwards, futures, swaps, and options are not permissible as they are based on sale of non-existent object, or involve too much speculation which is tantamount to gharar or "price of underlying asset is stochastic, and payoffs for traders' sum zero" (Kotby, 1996). Nevertheless, certain IFCs employed basic building blocks for development of complex instruments for risk management (Merna, \& Al-Thani,2008).

\section{Case for Alternatives Islamic Derivatives}

Conventional option implies "neither utility nor sum of money or financial right which may be waived" (Obaidullah, 2002), contracts are prohibited by consensus. Malaysia is an exception: in fact scholars find call options to be acceptable on the basis of characteristics and nature and asset can be sold and purchased (Obaidullah, 2002). On other hand, some scholars have evolved argument that call options are quite akin to Sharia'h permissible bai al-urboon, literally earnest money contract, whereby one party buys right to purchase from other party specified goods for specified price certain date (Vogal, 1998). Urboon differs from call option in a sense that in former option premium is adjusted in sale price when contract is confirmed whereas in latter buyer loses option premium even if he chooses to exercise option (Obaidullah, 2002). However, urboon cannot be used for generic commodities which limit its scope to replicate conventional option (Abubakar, 2004).

Options as independent contracts are concerned, they are Sharia'h prohibitory (Kamali, 1999). However, there is plenty of room for embedded options that can be structured within sharia' $h$ framework of Al Khiyar (Obaidullah, 1998).

\section{Khiyar al Shart or Stipulated Option}

\footnotetext{
${ }^{7}$ See Al Swailem, "Hedging in Islamic Finance" Occasional Paper 10 Islamic Research and Training Institute Jeddah for detail discussion on sharia'h legitimacy of derivatives.
} 
Khiyar al shart is option where party to contract or party not to contract given right to confirm or cancel contract within stipulated time (Obaidullah, 1998). Jurists belong to major schools of thought reached consensus on permissibility of Al khiyar (Obaidullah, 1998). However, certain qualifications have to met should be embedded in contract for benefits of parties, it should avoid potential conflict which may lead towards litigation (Teubner, 1998). These options have maturity length as time period is definite and known to parties at outset of contract (Antràs, 2005). Secondly, buyer can have goods in possession and seller can hold option price during option time period (Burkholder, 2006). Thirdly, under certain circumstances, settlement price may be adjusted by parties; in this way it may be different from contracted price (Bernstein, 1996). Having understood khiyar al shart framework, various financial risks associated with sukuk can hedged with embedded options (Ahmed \& Khan, 2007).

\section{Market risk management}

Ijarah sukuk being almost replica of conventional fixed and floating rate instruments is most popular structure until today (Rafay, Sadiq, \& Ajmal, 2017). Because of benchmark with LIBOR lessor has diametrically opposite interest with lessee (Bhatti \& Azmat, 2018). One way of managing risk in fixed rate ijarah sukuk is to construct same on basis of successive Master Ijarah Agreements whereby both parties keeping in view fluctuations of market rates renew terms of rent semiannually. Even if sukuk is based on floating rate ijarah parties are still exposed to fluctuation on bases of opposite interests (Abubakar, 2004). Situation can be handled in khiyar al shart framework whereby lessor may stipulate in contract if rent increases beyond upper bound, say 10\%, it would have an option to confirm or rescind contract (Obaidullah, 1998). On similar pattern, lessee may opt to have similar option of lowest bound, say 5\%. Thus, both parties can agree according to their willingness and capacity to bear risk (Easterbrook, \& Fischel, 1989).

Long-term murabaha sukuk, because of inherent lock-in capital structure until its maturity, is always exposed to rate of return risk (Elasrag, 2010). One solution to hedge this risk is parties agree to stipulate option to change payment structure with change in interest rates (Chisholm, 2011). If market rate goes up, installment can be agreed to higher with lesser duration and conversely if market rates decline, parties can agree on smaller installments with longer duration (Wilson, 2008). Even though this structure do not tend to increase return, it provides liquidity to affected party (Cowley \& Cummins, 2005).

As discussed earlier, conventional swaps based on interest hold no ground in sharia'h (Dusuki, 2009). There are various Islamic alternatives serve same purpose as conventional swaps (Obaidullah, 1999). Example helps understanding way Islamic swaps may achieve similar objective of risk management as of conventional swap (Ahmed, 2009). If Pakistani company makes payment of Rs.10000 to US company B which in turn pays US\$100 on same day at fix rate. Both companies can use money at respective risk profiles and then, at the end of swap period they return amount with same rate within fixed time. This is Islamic swap with free interest loan but help two companies with different risk profiles to hedge respective positions.

Similarly, liabilities in two currencies of two ijarah sukuk can swapped with help of financial intermediary where each party's risk exposure to currency or interest rates can be hedged to desired level. However, this kind of swap is possible only where sukuk market is relatively developed across the globe.

Another solution to reduce currency risk exposure in sukuk can be procured through the multicurrency denomination of issuance. For example, sukuk issue worth US\$ 1 billion can be divided into $€ 300$ million, $£ 300$ million pounds and the rest in US Dollar. This form of hedging in foreign exchange risk is widely used by the Chinese Government in issuance of bonds.

IDB sukuk also provides another arrangement whereby IDB guarantees against currency risk in sukuk profits. However, as per sharia'h requirements, this guarantee should be concluded in a separate contract and not as a part of the main contract between the issuer and the investors.

Tariq and Habib (2001) suggest another institutional arrangement whereby a subsidiary company in a liability-focused particular jurisdiction can be employed to pay the liabilities of the originator in foreign currency.

They further suggest that there may be a contractual arrangement between parties whereby parties agree that in case of price fluctuation, the gaining party would compensate the other for the loss he suffered in the transaction. This practice is applied in Sudan.

In addition to the supra arrangements, foreign exchange risks can be hedged with innovative sukuk structure. For example, any potential project in developing country capable of generating hard currency, say oil reserves which are yet to be extracted requiring huge capital outlay, can be subject of modarabah 
sukuk whereby the proceeds of oil after the completion of project would be transferred directly to an offshore escrow account wherefrom sukuk holder will receive periodical payments. This arrangement would be attractive for the foreign investors who avoid investment because of country or currency risks. The diagram of the structure is given below:

Exhibit. 4

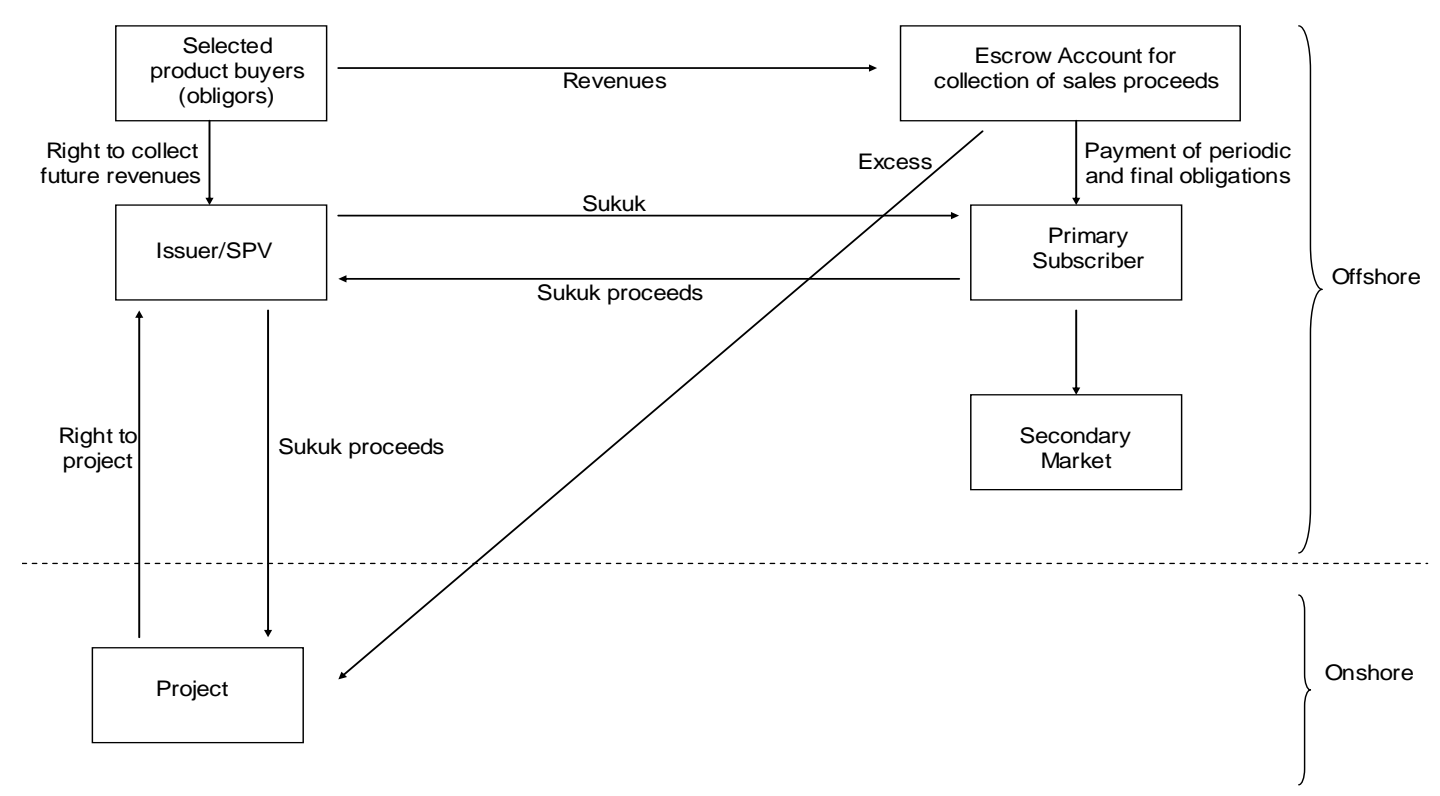

\section{Credit risk management.}

Islamic Financial Services Board (IFSB) has issued guiding principles in risk management for IFIs wherein principles regarding credit risk are also applicable to securitization structures. It has been maintained in the guideline that besides, the formulation of a strategy for financing on the basis of thorough due diligence, IFIs shall place "methodologies for measuring and reporting the credit risk exposures arising under each Islamic Financial Instrument" (Van Greuning, \& Iqbal, 2008). These guiding principles, without giving a clear outline, allow for permissible sharia'h compliant tools for credit risk hedging according to the requirements within the respective regulatory regimes. Given that each financing instrument bears different characteristics such as non-binding nature of some contract, the commencement stage of risk exposure varies. Therefore, guidelines provide that "credit risk shall be assessed separately for each financing instrument to facilitate appropriate internal controls and risk management systems" (Kithinji, 2010).

Considering the guidelines of IFSB there may be different legal and institutional tools to handle the credit and counter party risk in sukuk. One way of managing credit risk is in form of guarantee by the originator whereby an undertaking is given to make good the default in case of credit event. This technique was also used in IDB sukuk wherein "the bank provided the equivalent of a wrap by indicating that it would guarantee the performance on the underlying assets and by agreeing to buy back the asset pool at a specific price upon maturity of the sukuk" (RATTU, 2013).

Secondly, self-insurance whereby issuer would set aside a portion of cash flows into credit default pool is another way of hedging credit risk.

Although as per sharia'h principles in modarabah and musharaka sukuk originator/bank cannot guarantee the capital, however third party guarantee may work as a wrap-up provided that the guarantor is independent, financially and legally, in terms of its relation to the underlying contract. In Islamic finance third party guarantee given by an independent entity, which has an interest in the underlying asset, is 
permissible. For example, in istisna' sukuk the owner of the project has to be separate legal entity from the investors and SPV (the modarib). For the sake of comfort of the investors and for good credit rating the owner may provide guarantee in its own capacity or provide guarantee from any other acceptable party. However, the guarantee must be done without incurring any obligation on the consumers. Further if in cross-border sukuk structure, the guarantee given is governed by foreign law then it would entail good rating of the product.

An embedded option as to convertibility from debt to equity can also be inserted in the contract with the obligor company so that if it fails on the obligations the issuer may step into its ownership structure and can affect its affairs. Conversely the invested capital in a modarabah or musharakah contract may be transformed to debt in case of proven negligence or misconduct of the Mudarib or the Musharakah's managing partner (Safari, Ariff, \& Mohamad, 2014).

There may be another provision whereby an option can be secured in the contract where either servicer or issuer is given direct access to obligor company's bank account so that in case of default the provision of cash flows be affected by direct withdrawal therefrom (Massari, Gianfrate, \& Zanetti, 2014). This arrangement seems quite burdensome. However, it would certainly keep the obligor company under pressure to conduct the business with more diligence. Al Swailem suggests that for the purpose of credit risk management Islamic banks should also indulge in, inter alia, a thorough due diligence of the company seeking finance which would also minimize the risk of the default.

Sometimes if number of obligors under the sukuk structure is small that may expose the issuer to serious default. This phenomenon is quite akin to conventional securitization. "The default risk therefore can be managed by the SPV's buying receivable having a statistically large number of obligors and by analyzing the obligor" (Schwarcz, \& Ford, 2002). In conventional securitization there is another technique which provides that the securitization scheme can be designed with partial recourse to the loan originator (Alles, 2001). Though this technique poses no threat as to sharia'h compliance yet it may undermine the objective of achieving greater risk based ratios for the purpose of capital adequacy related to regulatory compliance.

From the investors' perspective the credit risk may be hedged with the embedded option in the contract whereby they may be given a right to opt to cancel the contract in case of defaults of the cash flows coupled with right to compensation.

Credit risk exposure does not necessarily remain over fixed term of the transaction; rather, it may hover around in volatile fashion. Thus, "when a cleanup call is agreed upon, for example, the originator is given the option of repurchasing all outstanding tranches once a certain limit is reached prior to the scheduled end of the transaction" (Gorton, 2008). This arrangement would allow credit risk to be shifted back to the originator's balance sheet after the sukuk structure has once been initiated.

\section{Liquidity risk management}

Long-term sustainable growth of Islamic markets largely depends on well-functioning secondary markets and on the introduction of liquidity-enhancing products (Iqbal, 2007). Since istisna', murabaha and salam sukuk are non-tradable financial contracts if sukuk are issued solely on the basis of those, it would lock-in the instrument until its maturity. One way of avoiding the risk is that all future flow receivables are pooled along with the tradable commodities, services and contracts like Ijarah, musharaka, modarabah or wakala so that the non-tradable part comprise less than $50 \%$ of the pool. This technique was also used in the IDB sukuk. This arrangement would make the product tradable in the secondary market without any sharia' $h$ prohibition.

Since IFCs provide for a variety of ways of financing there is a strong possibility that some IFIs are heavily involved in debt based financing whereas some others in tradable contracts. In this way an arrangement can be made on the line of inter-bank markets wherein those debt-based instruments are first transferred to the bank with potential tradable instruments and then the same are securitized in sukuk structures. This would help in developing the secondary market of such instruments and would also help in making inter-bank markets more efficient and organized.

Liquidity risk can further be mitigated if member countries of IDB transfer their illiquid assets to IDB balance sheet and then, IDB by making the portfolio of assets with dominant tradable assets would securitize the same in form of sukuk.

Although debt instruments cannot be negotiated by sale yet there is another possibility that the same can be transferred at par value to a third party in exchange for goods and services. This process can conveniently be entrusted to SPV in the arrangement which can acquire against them property or 
merchandise for a deferred price. The property acquired can be disposed of in any manner thus providing a limited liquidity to the sukuk. This methodology opens new avenues of liquidity in Islamic banks.

Another area of concern is represented by the fact that there are too few listing of sukuk across the globe as compared to conventional fixed income securities. Thus, financial markets starved for maximum cross listing of sukuk issuance which, at one hand, would familiarize the investors with the nature and structure of sukuk, and, on the other hand would stem uniformity and standardization of the product.

\section{Legal and Sharia'h Compliance Risk management}

For the purpose of tackling the title risk in bankruptcy issues associated with SPV it is necessary that proper perfection of legal interests in asset be achieved. In Sharia' $h$, only street registration is sufficient for the purpose of creation of interest in the underlying assets (DeLorenzo \& McMillen, 2007). Actual registration is not required. This feature is cost effective as the cost of actual transfer fee in form of stamp duty can be effectively mitigated. Secondly, it must be ensured that the underlying assets are not pledged or encumbered with creditors of originators. In order to avoid consolidation risk it is necessary that:

- The SPV is a distinct entity sans any ownership/shareholding relationship with the originator.

- The management of the SPV must be separate from the originator.

- The acquisition of the assets has to be done for a consideration, the sukuk proceeds.

- The assets are not operated as part of the business of the originator.

- The shareholders of SPV must not be indemnified by the originator.

Since in most of the emerging economies bankruptcy laws are not developed there is always a risk that a court disregards the sale of assets to SPV and claws back the same on the pretext that the transaction was not true sale. This risk can only be mitigated if the SPV is structured as an independent and distinct entity with reference to its funding and management so that it is at an arm's length from the originator. The desired result can be achieved by ensuring the complete segregation of SPV's books of account, record keeping, systems, capital, income, profits from those of the originator.

In addition to foregoing to ensure that only sukuk holders file for bankruptcy on the part of the SPV, a no-petition agreement can be employed. Further no- recourse clauses may be used wherein all contracting parties with SPV waive their right to sue for claims until the expiry of the sukuk transaction.

For the purpose of insulating sharia'h supervisory board from the management's influence, the spirit of AAOIFI Standard for appointment of sharia'h board is that its appointment should be made in annual general meeting of the company. But in most of Islamic states the practice of appointment, the decision-making process and the status of decision of sharia'h board lacks uniformity. Thus, this state of affair requires a joint effort by sharia' $h$ advisors, practitioners, and regulators to play their respective role to reduce major disagreement significantly if not to remove entirely (Alkhamees, 2013).

\section{Disclosure and Transparency as Risk Management Tools}

After the debacle of Enron, disclosure and transparency (D\&T) have become the hallmark of modern day financial markets. There is growing realization at global level that maximum D\&T reduces moral hazard and adverse selection and enhances efficiency and integrity of the markets and strengthens market discipline. Disclosure for the risk management purposes is so important that there is a growing upsurge on global scale to provide standardized guidelines and regulatory standards for financial markets. This phenomenon is manifested in the form of several reports and guidelines for disclosure, transparency and market discipline by international regulatory standards setters. As the sukuk's appearance in global market is new phenomenon and overwhelming attempts have been made to attract foreign investors therefore there is persistent need that disclosure standards in sukuk meet, at least, an adequate standard threshold. In view of the various unique risks underlying sukuk contracts and complex transaction woven around conventional securitization, D\&T as to arrangement of material contracts amongst all major players is a must. This would help investors before going for this venture to make an informed judgment as to their appetite for risk bearing. For that matter IFSB and AAOIFI have made joint effort and proposed various guidelines for the risk management, disclosure and transparency in sukuk structures.

The first amongst fifteen Guiding Principles for Risk Management by IFSB states that "IFIs have in place a comprehensive risk management and reporting process including appropriate board and senior management oversight to identify, measure, monitor, report and control relevant categories of risks and where appropriate, to hold adequate capital against these risks" (Karim \& Archer, 2013). A bare reading of 
the principle provides that enhanced D\&T dealings in the sukuk securitization ask for a systematic approach to devise a comprehensive risk management strategy.

Sukuk transaction being complex in nature cannot be carried out without a comprehensive information data and know-how particularly about the underlying asset pool and main players involved in the transaction. As in most of emerging markets the static pool data is not stored electronically it may incur huge costs, particularly when a greater level of manual effort is required. "The main data required for assessing transactions are internal ratings and historically verifiable default statistics for the purpose of validating those ratings" (De Laurentis, Maino, \& Molteni, 2011).

According to AAOIFI's Financial Accounting Standard No.17 (FAS 17) on accounting for investments in Islamic bonds (sukuk) the concept of disclosure entails only adequate disclosure implying that "financial statements should contain all material information necessary to make them useful to users" (Hosen, Kebir, \& Foong 2016). The standard further elaborates the term "adequate disclosure" into optimal aggregation, implying that financial statement should satisfy the user's need for information, and appropriate descriptions and clarifications.

Keeping in view complex nature of sukuk the Standard further requires on the part of issuer to disclose the face value of each category and percentage of each party in sukuk issue (Safari, Ariff, \& Mohamad 2014). It further lays stress for the disclosure of guarantors, if any, and the nature of guarantee given and the contractual relationship between the issuer and the manager of sukuk.

An overview of the guidelines emanates that it leaves many grey areas. For example, there is no mandate as to maintenance of electronic data base of credit risk exposure which would definitely bring about low cost of disclosure. Similarly, special disclosure as to any triggering event such as destruction of underlying assets has not been proposed. Further, there is nothing in the guidelines which requires for the disclosure with reference to servicer which under certain circumstances can create greater moral hazard. Thus, in view of the international developments as to D\&T, for instance US SEC Regulation AB for assetbacked securities, it seems there is a lot to be done in this field. It is quite understandable that international developments may be termed as an outcome of interest based banking and finance, yet D\&T stands at par level with IFIs. Even though guiding principles by AAOIFI and IFSB exhibit minimum threshold in reference to international developments regarding D\&T still there is very slow response in member countries, except Malaysia and Bahrain, for the adaptation of such guidelines. This state of affair is one of the major hindrances in further development of sukuk market.

On the basis of the supra discussion, risk management in sukuk entails an on-going reporting system exhibiting risks and risk management tools employed by the issuer. The risk of asymmetric information/moral hazard in sukuk structures can only be controlled if there is on-going reporting regarding static pool data coupled with maintenance of transparency at all level of contractual relationship.

\section{CONCLUSION}

The paper identifies the evolution, enabling legal and financial infrastructure and various risks of sukuk structures coupled with legal and institutional tools for risk management that can be applied in Sharia'h permissible hedging framework.

The sukuk structures have provided regulatory-induced impetus for the IFIs to monetize the highquality assets off their balance sheets. The robustness of the structure at global scale, even for non-Islamic issuers, has been proved with the fact of sukuk market touching US\$30 billion with double digit per annum growth since its inception almost five years ago.

While the sukuk structures are growing rapidly, their novelty is susceptible to various underlying risks such as market, credit, liquidity, legal and Sharia' $h$ compliance risks. If such risks are not hedged with Sharia'h compliant tools, this situation may arrest its prospective development. Further, integration of the sukuk structures into the modern global financial system will inevitably result in greater exposure to various levels of legal systems and compliance mandates. To survive the challenge of conventional fixedincome securities and derivatives, invention of ingenious Sharia' $h$ permissible risk management techniques are urgently required for hedging the risks in sukuk structures to optimal level, and maximum D\&T. Structured on Gharar and Riba, conventional derivatives including swaps, futures, forwards and options inherently repugnant to Sharia' $h$ have been unanimously discarded. Nonetheless, embedded options in Sharia'h framework of Al Khiyar and various other forms of guarantees (kafala) and Islamic swaps are a few amongst many Sharia' $h$ permissible alternative risk management tools. The pressing need, therefore, is 
the continuity of the financial innovations within Sharia'h framework so that the momentum of Islamic financial markets can be sustained.

Newly established international vehicles such as IFSB, AAOIFI, International Islamic Rating Agency, The International Islamic Financial Market and Bahrain based Liquidity Management Centre allow the wider integration of Islamic finance industry and its regulators with IMF, BIS and IASB by fostering improved rule-making and transparency. Nevertheless, the comparability with conventional securities in its true sense requires more convergence between these institutions and comprehensive legal and infrastructural developments for viable sukuk structures in emerging markets.

\section{REFERENCES}

Abdou, D. I. A. W. (2015). The global financial crisis and Islamic finance: a review of selected literature. Journal of Islamic Accounting and Business Research.

Adam, J. N. \& Thomas, A. (2004) "Islamic Fixed Income Securities: sukuk" in Jaffar, S. (2004) "Islamic Asset Management: Forming the Future for Shari'a-Compliant" Investment Strategies Euromoney Publications London at p. 73

Adam, N. J., \& Thomas, A. (2004). Islamic fixed income securities: sukuk. Islamic Asset Management London: Euromoney Books.

Ahmad, A. U. F., \& Hassan, M. K. (2006). The time value of money concept in Islamic finance. American Journal of Islamic Social Sciences, 23(1), 66.

Ahmad, M. I., \& Shabbir, M. G. (2006). Islamic Banking. Journal of State of the Art, 2(1), 1-38.

Ahmed, H. (2005). Operational Structure for Islamic Equity Finance-Lessons from Venture Capital (No. 212). The Islamic Research and Teaching Institute (IRTI).

Ahmed, H., \& Khan, T. (2007). 10 Risk management in Islamic banking. Handbook of Islamic banking, 144.

Al Rahahleh, N., Ishaq Bhatti, M., \& Najuna Misman, F. (2019). Developments in risk management in Islamic finance: A review. Journal of Risk and Financial Management, 12(1), 37.

Alam, N., Gupta, L., \& Shanmugam, B. (2017). Islamic finance: A practical perspective. Springer.

Alamad, S. (2017). Financial innovation and engineering in Islamic finance. Springer International Publishing.

Alessandri, P., \& Drehmann, M. (2010). An economic capital model integrating credit and interest rate risk in the banking book. Journal of Banking \& Finance, 34(4), 730-742.

Ali, S. S. (2005). Islamic capital market products: developments and challenges. Islamic Research and Training Institute, Islamic Development Bank.

Alkhamees, A. (2013). The impact of Shari'ah governance practices on Shari'ah compliance in contemporary Islamic finance. Journal of Banking Regulation, 14(2), 134-163.

Alles, L. (2001). Asset Securitization and Structured Financing: Future Prospects and Challenges for Countries in Emerging Markets. IMF Working Papers, 2001(147).

Alswaidan, M. W. (2017). An investigation of Sukuk structure risk (Doctoral dissertation, University of Portsmouth).

Antràs, P. (2005). Incomplete contracts and the product cycle. American economic review, 95(4), 10541073.

Anwer, Z., \& Habib, F. (2019). Re-visiting current debate on Shar1 'ah position of derivatives. Journal of Islamic Business and Management, 9(1), 64-83.

Ariff, M. (2014). Whither islamic banking?. The World Economy, 37(6), 733-746.

Askari, H., Iqbal, Z., \& Krichene, N. (2012). The Foundation of the Islamic Financial System. Journal of Islamic Banking \& Finance, 29(1).

Banks, E. (2005). Liquidity risk. New York, NY: Springer.

Baruya, P. (2017). International finance for coal-fired power plants. IEA Clean Coal Centre.

Bernstein, L. (1996). Merchant law in a merchant court: Rethinking the code's search for immanent business norms. University of Pennsylvania Law Review, 144(5), 1765-1821.

Berschadsky, A. (2000). Innovative Financial Securities in the Middle East: Surmounting the Ban on Interest in Islamic Law. U. Miami Bus. L. Rev., 9, 107. 
Bhatti, A., \& Azmat, S. (2018). Rethinking Islamic Finance: Markets, Regulations and Islamic Law. Routledge.

Burkholder, N. C. (2006). Outsourcing: The definitive view, applications, and implications. John Wiley \& Sons.

Chapra, M. U. (2007). The case against interest: Is it compelling?. Thunderbird International Business Review, 49(2), 161-186.

Chisholm, A. M. (2011). Derivatives demystified: a step-by-step guide to forwards, futures, swaps and options. John Wiley \& Sons.

Colon, J. C. (2010). Choice of law and Islamic finance. Tex. Int'l LJ, 46, 411.

Cowley, A., \& Cummins, J. D. (2005). Securitization of life insurance assets and liabilities. Journal of Risk and Insurance, 72(2), 193-226.

Crotty, J. (2009). Structural causes of the global financial crisis: a critical assessment of the 'new financial architecture'. Cambridge journal of economics, 33(4), 563-580.

Dchieche, A., \& Aboulaich, R. (2016). New approach to model Salam contract for profit and loss sharing. International Journal of Applied Engineering Research, 11(2), 909-916.

De Laurentis, G., Maino, R., \& Molteni, L. (2011). Developing, validating and using internal ratings: methodologies and case studies. John Wiley \& Sons.

DeLorenzo, Y. T., \& McMillen, M. J. (2007). Law and Islamic finance: an interactive analysis. Islamic finance: The regulatory challenge, 136.

Dewi, G. (2012). The Application of Islamic Economic Security System for a Better Human Security in Indonesia. Indonesian J. Int'l L., 10, 315.

Dusuki, A. W. (2009). Challenges of Realizing Maqasid Al-shari'ah (objectives of Shari'ah) in the Islamic Capital Market: Special Focus on Equaty-based Sukuk Structures. International Shari'ah Research Acedemy for Islamic Finance (ISRA).

Dusuki, A. W. (2010). Do equity-based Sukuk structures in Islamic capital markets manifest the objectives of Shariah??. Journal of Financial Services Marketing, 15(3), 203-214.

Easterbrook, F. H., \& Fischel, D. R. (1989). Corporate Contract, The. Colum. L. Rev., 89, 1416.

Elasrag, H. (2010). Global Financial crisis and Islamic finance. Available at SSRN 1591563. ...(2011). Principals of the Islamic finance: A focus on project finance. Available at SSRN 1806305.

El-Gamal, M. A. (2000). An introduction to modern Islamic economics and finance. In Fourth Harvard University Forum on Islamic Finance. Islamic finance: The task ahead, Cambridge.

Frame, J. D. (2002). The new project management: tools for an age of rapid change, complexity, and other business realities. John Wiley \& Sons.

Gorton, G. B. (2008). The panic of 2007 (No. w14358). National Bureau of Economic Research.

Hassan, M. K., Aliyu, S., \& Brodmann, J. (2017). An introduction to Islamic banking and finance. In The Most Important Concepts in Finance. Edward Elgar Publishing.

Hidayah, N. N., Lowe, A., \& De Loo, I. (2021). Identity drift: the multivocality of ethical identity in Islamic financial institution. Journal of Business Ethics, 171(3), 475-494.

Hosen, M., Kebir, A., \& Foong, N. D. N. (2016). The pitfalls of the Malaysian sukuk industry: issues and challenges in practice. Research Gate, Working Paper.

Huault, I., \& Rainelli-Le Montagner, H. (2009). Market shaping as an answer to ambiguities: The case of credit derivatives. Organization studies, 30(5), 549-575.

Hussain, M. M., Shahmoradi, A., \& Turk, R. (2015). An overview of Islamic finance.

Hussain, M., Shahmoradi, A., \& Turk, R. (2016). An overview of Islamic finance. Journal of International Commerce, Economics and Policy, 7(01), 1650003.

Hussey, R., \& Ong, A. (2005). International financial reporting standards desk reference: overview, guide, and dictionary.

Iqbal, M., \& Llewellyn, D. T. (Eds.). (2002). Islamic banking and finance: new perspectives on profit sharing and risk. Edward Elgar Publishing.

Iqbal, Z. (2007). Challenges facing Islamic financial industry. Journal of Islamic Economics, Banking and Finance, 3(1), 1-14.

Jobst, A. A. (2007). The economics of Islamic finance and securitization. The Journal of Structured Finance, 13(1), 6-27. 
Kamali, M. H. (2007). A shari 'ah analysis of issues in Islamic leasing. Journal of King Abdulaziz University: Islamic Economics, 20(1).

Karim, R. A. A., \& Archer, S. (2013). Islamic Finance: The new regulatory challenge. John Wiley \& Sons.

Kithinji, A. M. (2010). Credit risk management and profitability of commercial banks in Kenya.

Kok, S. K. (2014). Islamic finance and the global economy: An exploration of risk management and governance within shariah finance (Doctoral dissertation, University of Liverpool).

Kothari, V. (2006). Securitization: the financial instrument of the future (Vol. 385). John Wiley \& Sons.

Lahsasna, A., Hassan, K. M., \& Ahmad, R. (2018). Forward Lease Sukuk in Islamic Capital Markets. Springer Books.

$\mathrm{Li}, \mathrm{S}$. (2003). Future trends and challenges of financial risk management in the digital economy. Managerial Finance.

Linder, S. H. (1999). Coming to terms with the public-private partnership: A grammar of multiple meanings. American behavioral scientist, 43(1), 35-51.

Massari, M., Gianfrate, G., \& Zanetti, L. (2014). The valuation of financial companies: Tools and techniques to measure the value of banks, insurance companies and other financial institutions. John Wiley \& Sons.

McMillen, M. J. (2006). Islamic capital markets: developments and issues. Capital Markets Law Journal, l(2), 136-172.

Moghul, U. F., \& Safar-Aly, S. H. (2014). Green Sukuk: The Introduction of Islam's Environmental Ethics to Contemporary Islamic Finance. Geo. Int'l Envtl. L. Rev., 27, 1.

Muhammad, M. Z., \& Chong, R. (2007). The contract of bay'Al-Salam and Istisna'in Islamic commercial law: A comparative analysis. Labuan e-Journal of Muamalat and Society (LJMS), 21-28.

Nagaoka, S. (2012). Critical overview of the history of Islamic economics: Formation, transformation, and new horizons. Asian and African Area Studies, 11(2), 114-136.

Nasir, A., \& Farooq, U. (2017). Analysis of value at risk of Sukuk and conventional bonds in Pakistan. Journal of Islamic Accounting and Business Research.

Obaidullah, M. (1998). Financial engineering with Islamic options. Islamic Economic Studies, 6(1). (2005). Islamic financial services.

(2008). Introduction to Islamic microfinance. Mohammed Obaidullah, Introduction to Islamic Microfinance, IBF Net Limited.

Radzi, R. M., \& Muhamed, N. A. (2019). Are sukuk debt or equity? A classification of sukuk by regulatory bodies and credit rating agencies. Journal of Emerging Economies and Islamic Research, 7(2), 7584.

Rafay, A., Sadiq, R., \& Ajmal, M. (2017). Uniform framework for Sukuk al-Ijarah-a proposed model for all madhahib. Journal of Islamic Accounting and Business Research.

Rattu, M. (2013). Exploring Legal, Regulatory and Shari 'ah Compliance Issues in Islamic Financial Instruments: Derivatives and Sukuk (Doctoral dissertation, Durham University).

Rethel, L. (2011). Whose legitimacy? Islamic finance and the global financial order. Review of international political economy, 18(1), 75-98.

Safari, M., Ariff, M., \& Mohamad, S. (2014). Sukuk securities: New ways of debt contracting. John Wiley $\&$ Sons.

Schwarcz, S. L., \& Ford, A. D. (2002). Structured finance: A guide to the principles of asset securitization. Practising Law Institute.

Siddiqui, A. (2008). Financial contracts, risk and performance of Islamic banking. Managerial finance.

Siddiqui, S. A. (1998). Mudarabah Finance: A Critical Review of Bacha's Model and Modarabas of Pakistan. Journal of Accounting Commerce and Finance: Islamic perspective.

Taman, S. (2011). The concept of corporate social responsibility in Islamic law. Ind. Int'l \& Comp. L. Rev., $21,481$.

Tariq, A. A. (2004). Managing financial risks of sukuk structures. Loughborough University, UK. September (mimeo).

Tariq, A. A., \& Dar, H. (2007). Risks of Sukuk structures: Implications for resource mobilization. Thunderbird International Business Review, 49(2), 203-223.

Teubner, G. (1998). Legal irritants: good faith in British law or how unifying law ends up in new divergencies. The modern law review, 61(1), 11-32.

Thomas, A. S., Cox, S., \& Kraty, B. (Eds.). (2005). Structuring Islamic finance transactions. Linnius. 
Van Greuning, H., \& Iqbal, Z. (2008). Risk analysis for Islamic banks. World Bank Publications. Wilson, R. (2008). Innovation in the structuring of Islamic sukuk securities. Humanomics.

Witbrodt, M., \& Shapiee, R. (2014). Academic entrepreneurship and muamalat: Risk and money in commercial transactions from an Islamic Perspective. Pertanika Journal of Social Sciences \& Humanities, 22, 21-44. 